\title{
Histological Study of the Trachea In Indigenous Male Turkey (Meleagris gallopava)
}

\author{
A. M. AL-Mussawy \\ Coll. of Vet. Med./ Unive. \\ of Kufa
}

\author{
N. H. AL-Mehanna \\ Coll. of Vet. Med./ Unive. \\ of Al-Qadysia
}

\author{
E. F. AL-Baghdady \\ Coll. of Vet. Med./ Unive. \\ of Al-Qadysia
}

\section{Abstract}

The present study was conducted on five healthy indigenous male turkeys at the first year of their age and live weight was $(4715 \pm 43.3 \mathrm{gm})$ collected from the center of Diwanyia city, our need to have a base line data on the respiratory system of this abundant species of bird in Iraq. It is expected that this work will provide a pivot for future research and subsequent clinical application as regards the biology of the turkey.After birds preparation the trachea dissected out and washing by normal saline solution $(0.9 \% \mathrm{Nacl})$, then were fixed immediately in $10 \%$ formalin, then get ready for routine histological processing. Trachea was lined by respiratory epithelium (ciliated, pseudostratified columnar epithelium) with simple branched tubular mucous glands and goblet cells. Laminapropria-submucosa of the trachea was supported by hyaline cartilages and comprised of loose connective tissue, with large bundles of collagen fibers.

\section{Introduction}

The respiratory system generally consists of organs that allow for a union between air and blood such that exchange of gases (mainly $\mathrm{Co}_{2}$ and $\mathrm{O}_{2}$ ) is made possible. In addition, the respiratory system plays a vital role in thermoregulation. The sense of smell and voice are associated with it. $(1 ; 2 ; 3)$.Tracheal wall in general consists of respiratory epithelium (ciliated, pseudostratified columnar epithelium) with goblet cells. Beneath epithelium, the propriasubmucosa is comprised of loose connective tissue and tracheal glands which are serous and mucous type. Tracheal wall is supported by complete (Oshaped) or none (C- or U-shaped) hyaline cartilaginous rings covered externally by tunica adventitia or serosa. There are diffuse lymphocytes between respiratory epithelium and cartilage, and there is a longitudinally oriented striated muscle located at the periphery of the trachea in a lateral position $(4 ; 5 ; 6 ; 7 ; 8)$. Epithelium lining of the trachea in birds like (Turkey, Bursa roller pigeon (Columba livia), and goose) is mucous type in secretion by either intraepithelial simple alveolar mucus glands, or goblet cells $(4 ; 9 ; 10 ; 6 ; 11 ; 12$; and 13).(10) mention that in birds, tracheal epithelium contains anterior portion numerous, simple alveolar mucous glands whereas in the posterior portion of the trachea, the glands are replaced by goblet cells which form 'intraepithelial glands'.Complete cartilaginous rings of trachea in birds are hyaline cartilage. The diameters of these rings vary according to the types of birds and ossification of the rings is common in Geese and Ducks (14). The matrix (ground substance) contains the lacunae which confines chondrocytes, small clusters of chondrocytes, called isogenous groups, which are frequently observed. They are the result of cell division of chondrocytes. Cartilage matrix is usually invested by a perichondrium whose inner layer is chondrogenic, containing cells with the capacity to become chondroblasts; its outer portion is dense irregular connective tissue (10).

\section{Materials and methods}

Specimens were prepared by bleeding of birds with the cutting of the major neck blood vessels after making an skin incision in the neck and separation of trachea away from the site of cutting to avoid aspiration of blood and spoiling of the respiratory system.Each trachea were dissected out and washed with normal 
saline solution $(0.9 \% \mathrm{Nacl})$, next divided into proximal parts extend from the cricoid cartilage of the larynx to the thoracic inlet and distal part extend from the thoracic inlet to the first tracheosyringeal cartilage, then were fixed right away in $10 \%$ formalin at room temperature. Subsequently the routine histological processes were performed and used three stains: - (15).

\section{1- Harris Hematoxylin \& Eosin stain:-} Which was routine stain used to demonstrated the general histological structures

2- Periodic acid-shiff (PAS) Stain: - Used this stain to show the type of secretion.

\section{Results}

Trachea of turkey was appeared as empty cartilaginous tube consists of proximal and distal parts. It was line by ciliated, pseudostratified columnar epithelium (Fig. 1). The mean thickness at the proximal and distal part of trachea were $(102 \pm 13 \mu \mathrm{m})$ and $(68 \pm 3.5 \mu \mathrm{m})$ respectively. The mean heights of the cilia were similar at both parts of trachea $(4.5 \pm$ $0.9 \mu \mathrm{m})$. The epithelium contained large numbers and various sizes of acini of the simple branched tubular mucous glands which penetrated the epithelium toward the tracheal cavity (Fig. 1A). It lined by pyramid cells contain mucous droplets and basal flattened nuclei, which gave the positive reactions with the PAS stain (Fig. 1B).In the proximal part, the large simple branched tubular mucous glands occupied the most thickness of the epithelium and caused the squeezing on the epithelial cells and converted it to short cells layer. The mean diameter of the large acini and its cells number were $(79 \pm 2.9 \mu \mathrm{m})$ and $(22.84 \pm 0.31)$ respectively, while the mean diameter of the small acini and its cells number were $(45 \pm 2 \mu \mathrm{m})$ and $(11.9 \pm$ $0.31)$ respectively.In the distal part of the trachea, most of these glands compensated by plentiful numbers of the goblet cell groups, filled by mucins and the peripherally flattened nuclei, which form
3- Van Gieson's Stain:- Used this stain for collagen fibers detection.

\section{Morphometric Measurements:}

Five sections of each trachea were taken for studied by use of ocular micrometer and the following data were recorded: (16)

1- The thickness of the proximal and distal tracheal wall, wall at overlapping, epithelium, cartilage, and muscles.

2- The diameter of the tracheal mucous epithelial acini and numbers of its cells.

3- Height of the cilia of the tracheal epithelium. 'intraepithelial glands' (Fig. 2,3,4).The lamina propria-submucosa were loose connective tissue, contained large bundles of collagen fibers, blood vessels, and numerous aggregations of lymphocytes (Fig. 5,6).The building units of the tracheal walls were the overlapped complete rings of hyaline cartilages. The matrix (ground substance) of the tracheal cartilages were partially ossified and contained the scattered lacunae which limited the chondrocytes, it was entirely surrounded by perichondrium which were continued with the adventitial coat of the trachea. The mean thickness of the proximal and distal tracheal cartilages were $(362 \pm 23 \mu \mathrm{m})$ and $(464 \pm 11 \mu \mathrm{m})$ respectively.The skeletal muscles (Sternotrachealis muscles) firmly attached with the adventitial coat of the left and right lateral sides of the proximal part and approximately half of the distal part of the tracheal wall (Fig. 3), the mean thickness of these muscles at the proximal and distal parts of the trachea were $(560 \pm$ $18 \mu \mathrm{m})$ and $(1292 \pm 82 \mu \mathrm{m})$ respectively. The mean thickness of the tracheal wall at the overlapped part at the proximal and distal parts of the trachea were $(724 \pm 30$ $\mu \mathrm{m})$ and $(682 \pm 7 \mu \mathrm{m})$ respectively, and at the non-overlapped part were $(566 \pm 143$ $\mu \mathrm{m})$ and $(556 \pm 196 \mu \mathrm{m})$ respectively. 


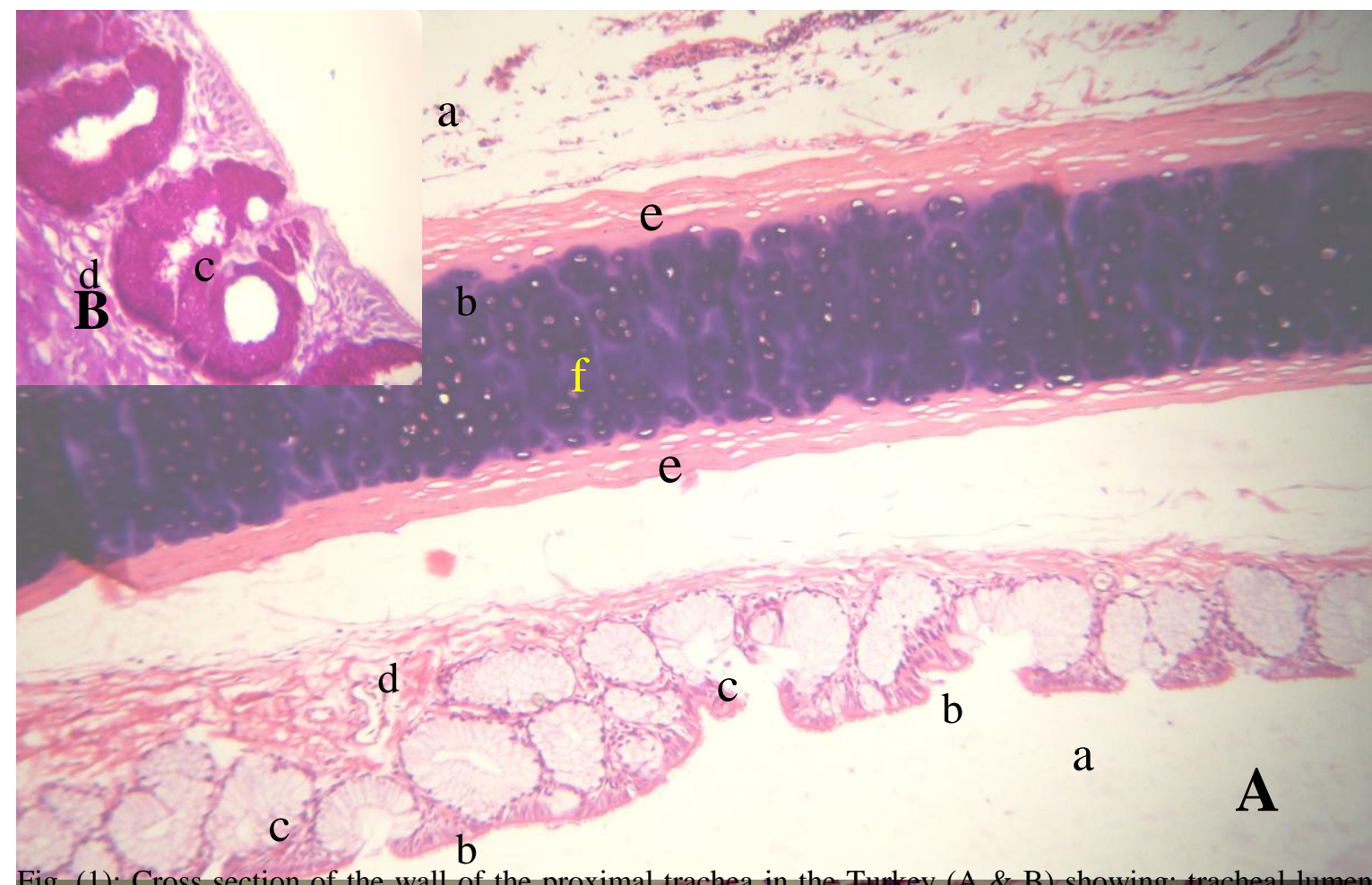

Fig. (1): Cross section of the wall of the proximal trachea in the Turkey (A \& B) showing: tracheal lumen (a), ciliated, pseudostratified columnar epithelium (b), simple branched alveolus mucous glands (c), 16ose connective tissue of lamina-properia-submucosa $(d)$, perichondrium $(\mathrm{e})$, tracheal hyaline cartilage $(\mathrm{f})$,

H \& E stain X100 A (Magnificafiơn zoom 4) -

PAS stain X400 B (Magnification zoom 2)

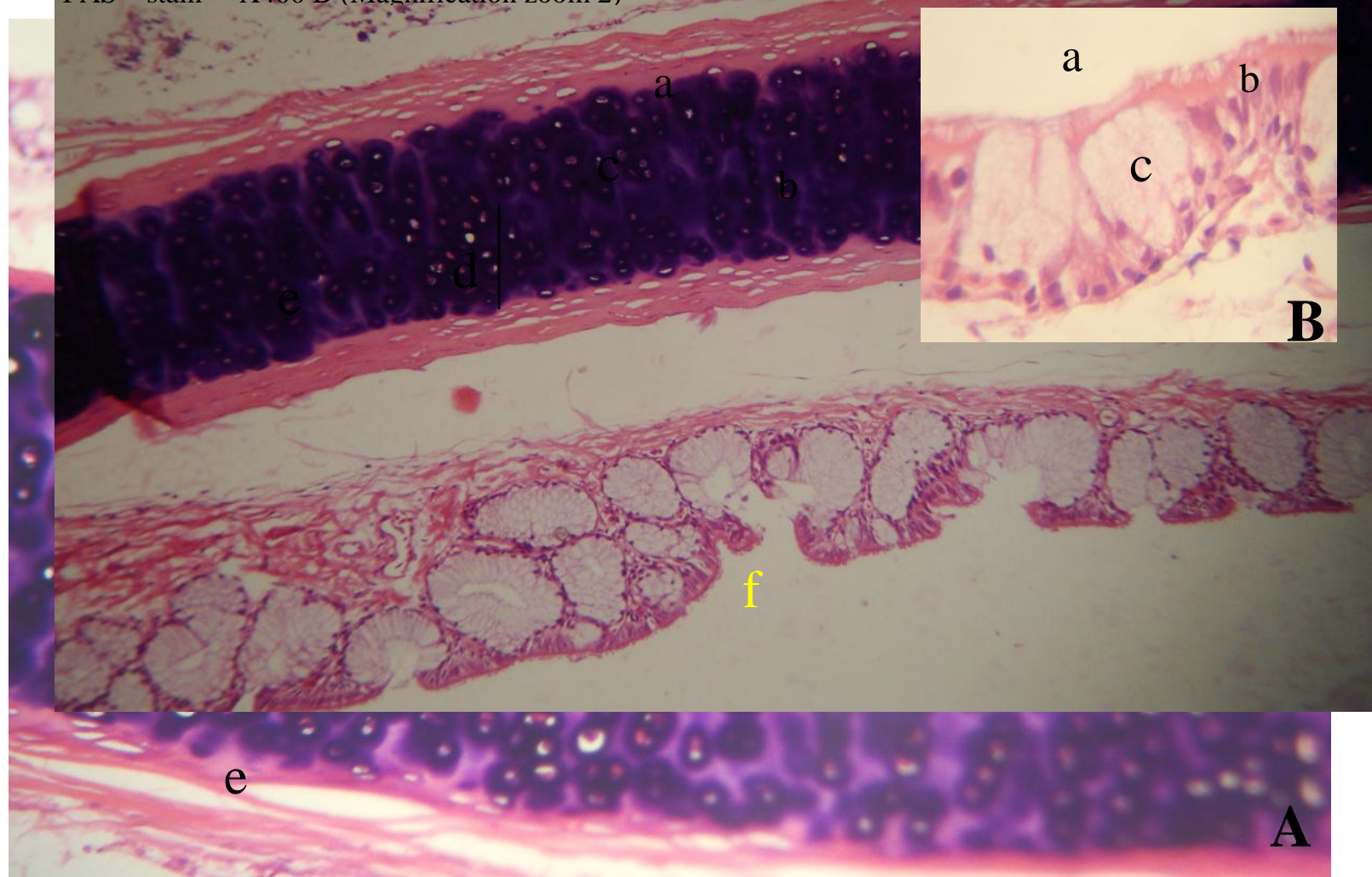

Fig. (2): Cross section of the wall of the distal trachea in the Turkey (A\&B) showing: tracheal lumen (a), ciliated, pseudostratified columnar epithelium (b), groups of the goblet cells (intraepithelial glands) (c) loose connective tissue of lamina proparia-submucosa (d) perichondrium (e) hyaline cartilage (f)

$\mathrm{H} \&$ E stain X100 A (Magnification zoom 2)

H \& E stain X100 B (Magnification zoom 4) 


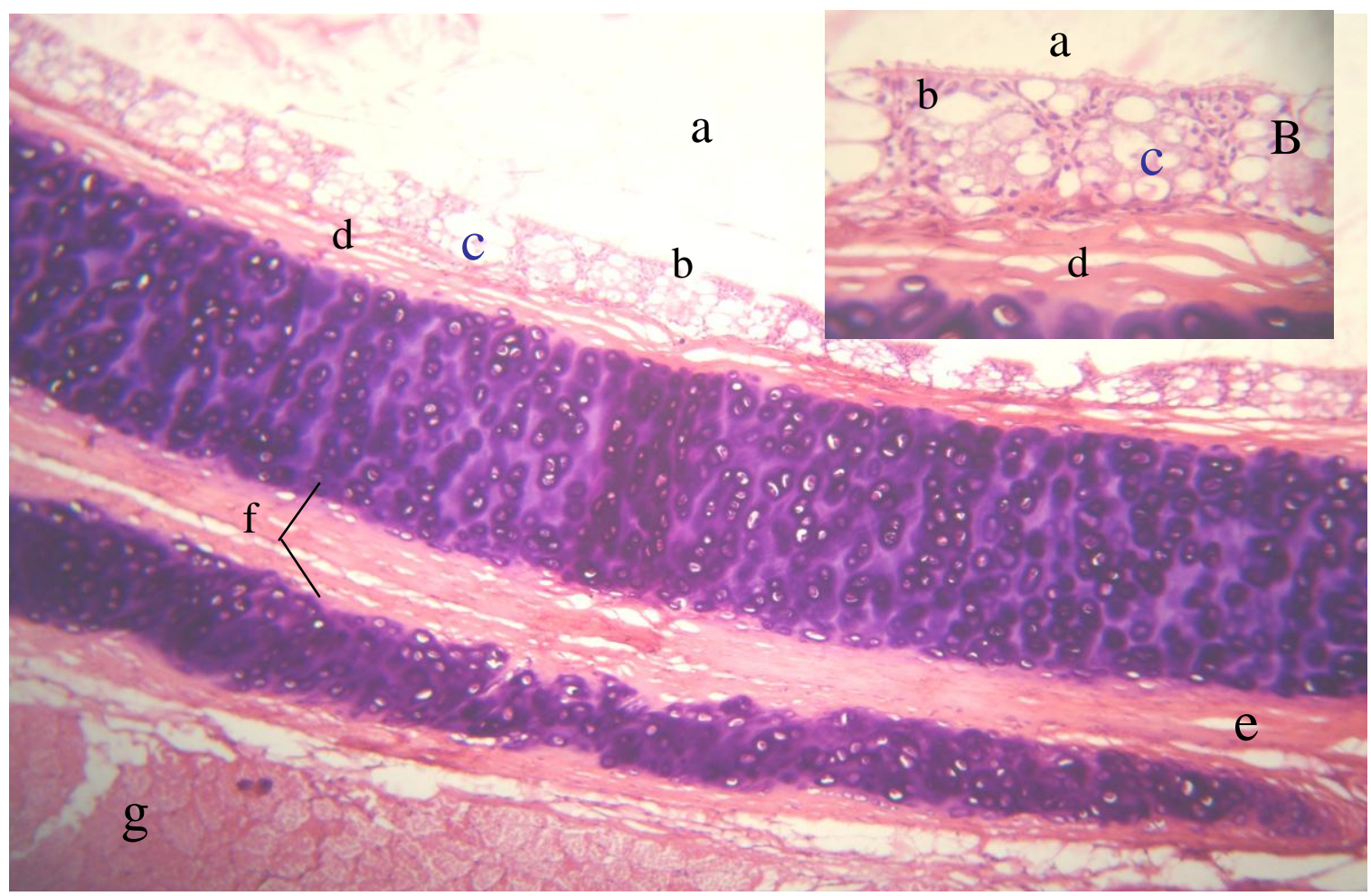

Fig. (3): Cross section of the wall of the distal trachea at the overlapping region in the Turkey (A\&B) showing: tracheal lumen (a), ciliated, pseudostratified columnar epithelium (b), groups of the goblet cells (intraepithelial glands) (c) loose connective tissue of lamina proparia-submucosa (d) perichondrium (e) overlapping tracheal hyaline cartilage (f) sternotrachealis muscle (g).

H \& E stain X100 A (Magnification zoom 2)

H \& E stain X100 B (Magnification zoom 3)

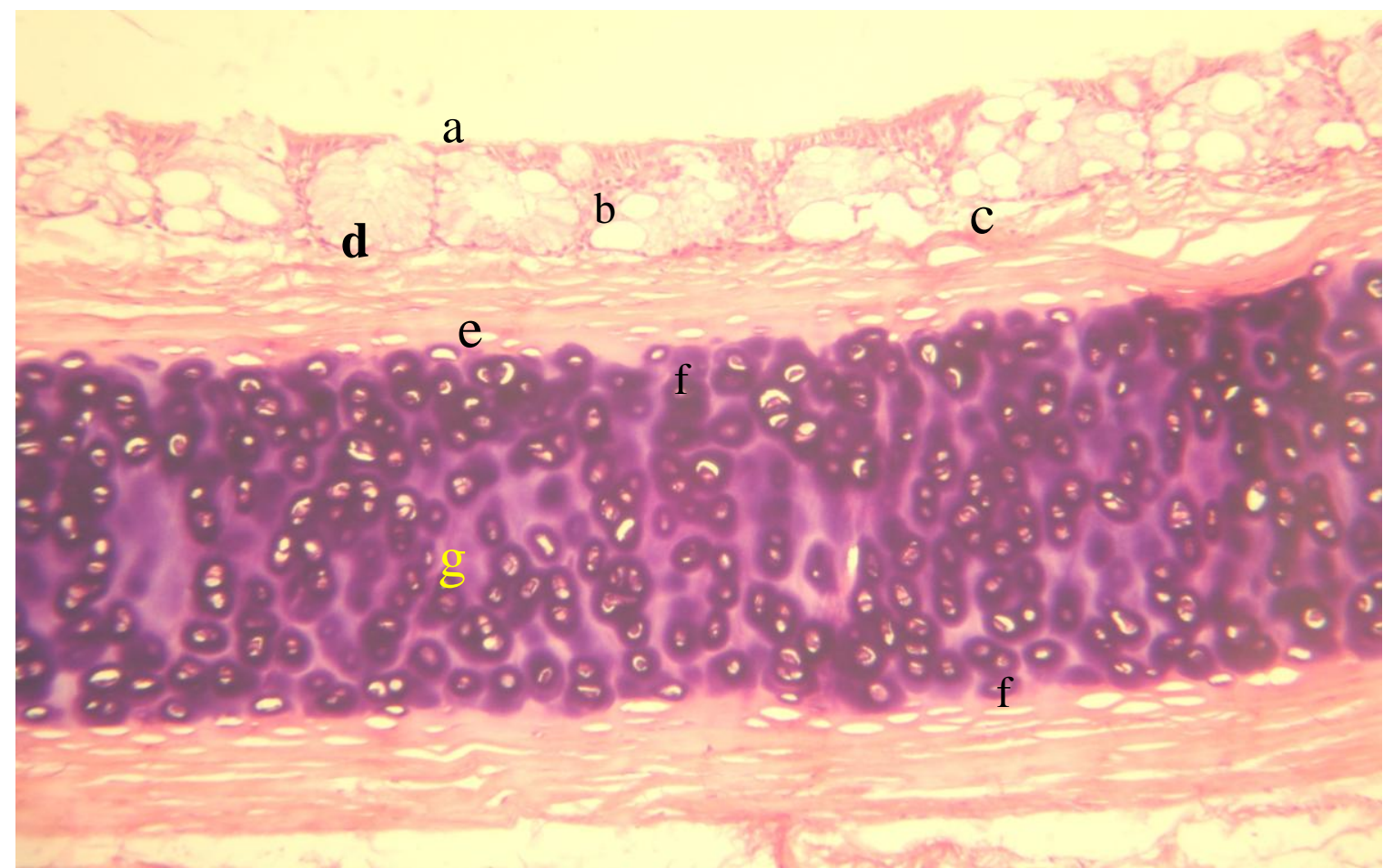

Fig. (4): Cross section of the wall of the distal trachea at the nonoverlapping region in the Turkey showing: tracheal lumen (a) ciliated, pseudostratified columnar epithelium (b) groups of goblet cells (intraepithelial glands) (c) acini of mucous glands (d), dense irregular connective tissue of the submucosa rich with bundles of collagen fibers (e) perichondrium (f). Hyaline cartilage (g)

H \& E stain X100 (Magnification zoom 3) 


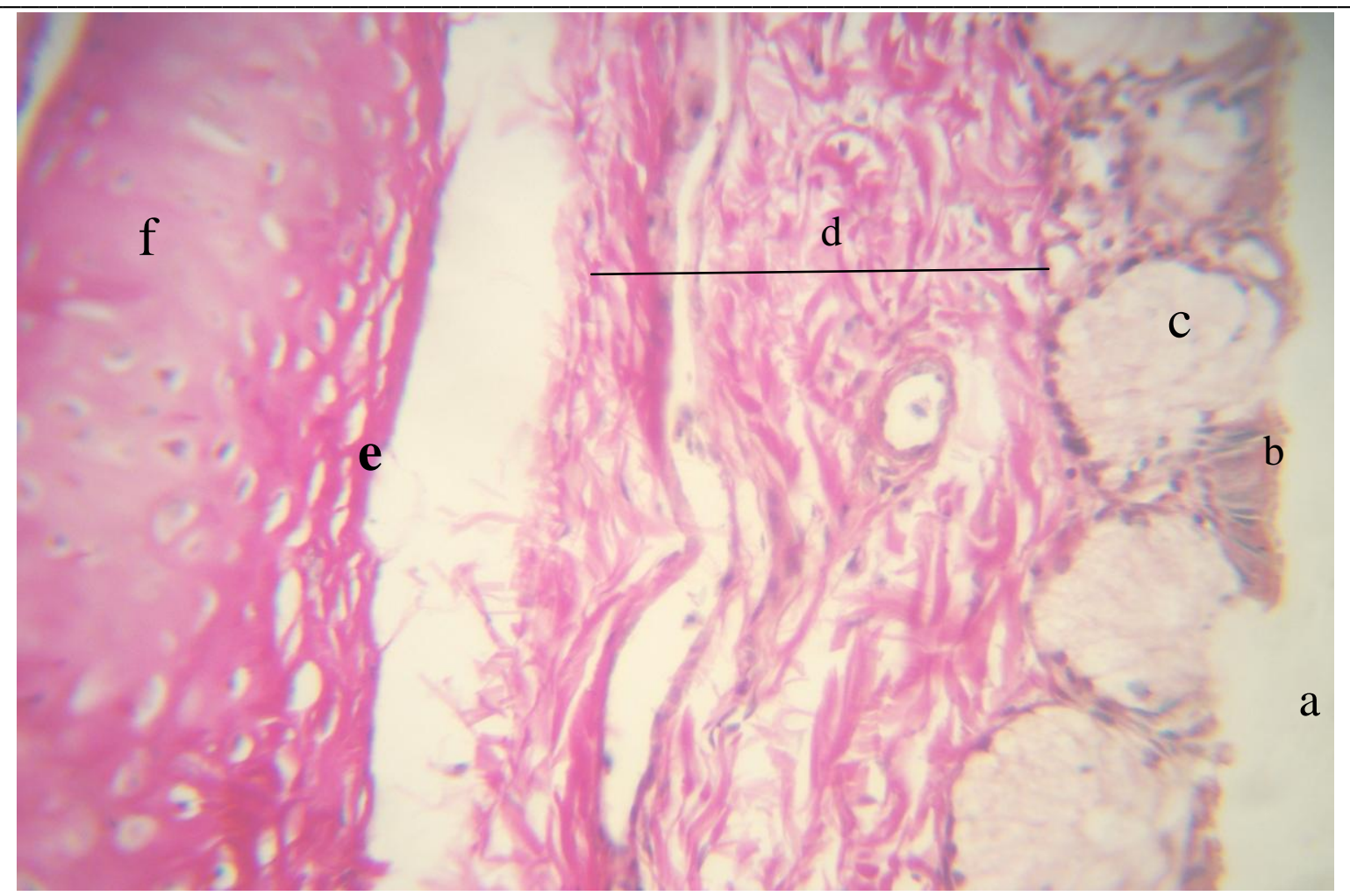

Fig. (5): Cross section of the wall of the proximal trachea in the Turkey showing: tracheal lumen (a) ciliated, pseudostratified columnar epithelium (b) simple alveoli mucous glands (c), loose connective tissue of lamina-properia-submucosa rich with bundles of collagen fibers (d), perichondrium (e), tracheal hyaline cartilage (f),

V G stain X 400 (Magnification zoom 2)

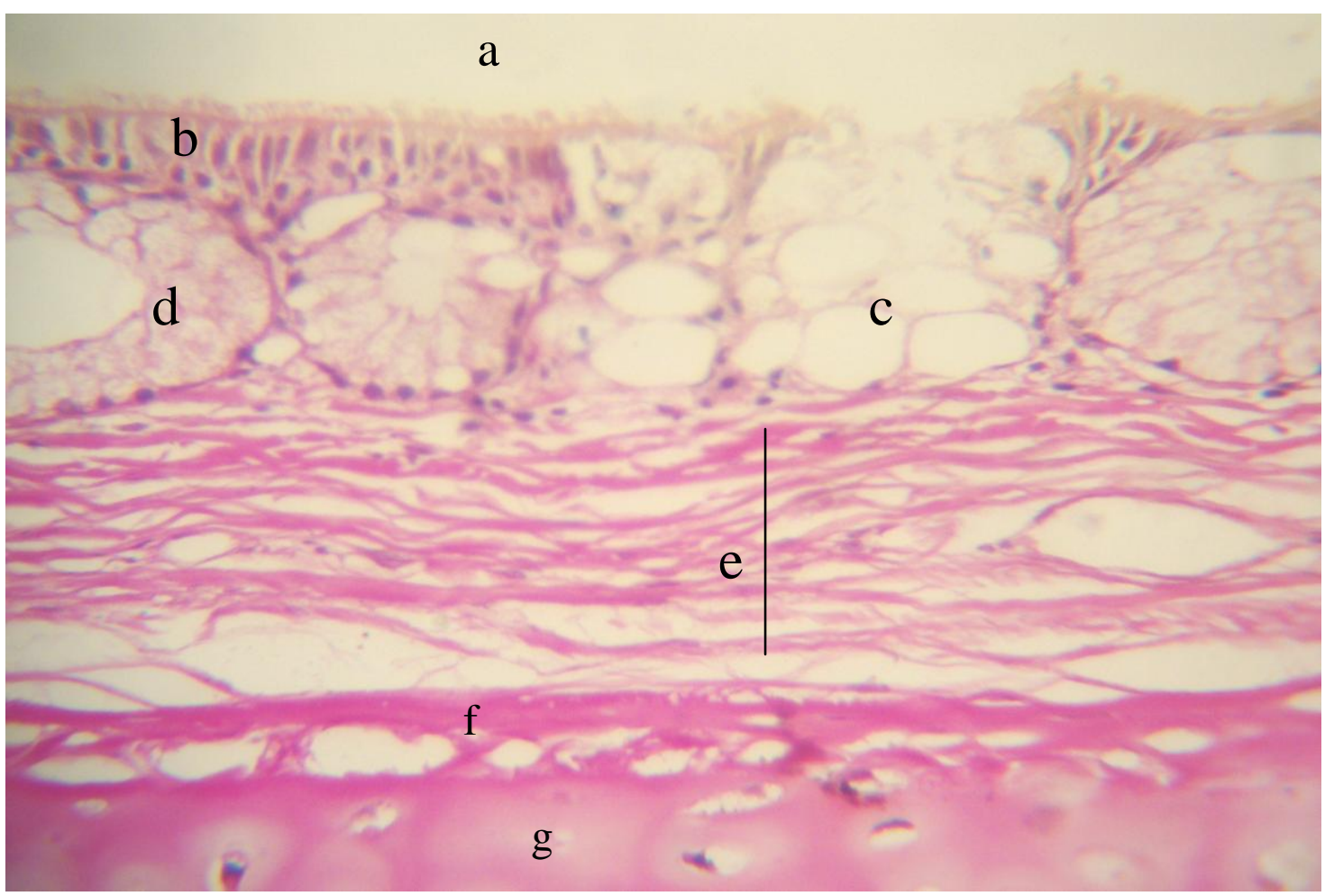

Fig. (6): Cross section of the wall of the distal trachea in the Turkey showing: tracheal lumen (a), ciliated, pseudostratified columnar epithelium (b), groups of goblet cells (intraepithelial glands) (c), alveoli of mucous glands (d), loose connective tissue of lamina propria-submucosa rich with bundles of collagen fibers (e), perichondrium (f), tracheal hyaline cartilage $(\mathrm{g})$.

V G stain X 400 (Magnification zoom 2) 


\section{Discussion}

Trachea in turkey were lined by ciliated, pseudostratified columnar epithelium with the large mucous glands in the proximal part and numerous of the goblet cell groups in distal part of trachea, the cilia move in coordination with one another the total effect being that like a wave to move secretions in the trachea and bronchi and scavenging cells which consume bacteria toward the oral cavity, these features act as defensive elements of bird health $(17 ; 7 ; 18$; and 8$)$ these results were compatible with (4); (14); (9); (5); (10); (6); (19) in turkey and bursa roller pigeon.In this study the tracheal walls contain the overlapping complete rings of hyaline cartilages which partially ossified this consequence well-matched with (4); (14); (9); (5); (10); (6); (7); (19); (18); (8) in birds generally. Some measurements of histological features were proved the trachea responsible fore sounds and defense mechanism functions, decreasing in epithelial thickness toward distal part about $(30 \mu \mathrm{m})$ and mucus glands replaced by numerous of goblet cells. While increased in thickness in hyaline cartilage about $(100 \mu \mathrm{m})$, and thickness sternotrachealis muscle about $(700 \mu \mathrm{m})$ referred to the distal part of trachea act as attachment of this muscle which responsible fore tracheal movements $(20$; $9 ; 21 ; 22)$.

\section{References}

1. Lbe, C.S., Onyeanusi, B.I., Salami, S.O., Umosen, A.D., and Maidawa, S.M. (2008): Studies of the major respiratory pathways of the West african guinea fowl (Numida meleagris galeata): The Morphometric and Macroscopic Aspects. Inter. J. of Poul. Sci. 7 (10): 997-1000

2. Reece, W.O. (2005): Avian respiratory system morphology. In: Function Anatomy and Physiology of Domestic Animals $3^{\text {rd }}$ (ed.): Lippincott Williams and Wilking. PP. 230-268

3. Nash, H. (2007): Respiratory System of Birds: Anatomy and Physiology. Pet Edu. com Drs. Foster \& Smiths source for expert pet information

4. Yersin, A.G., Eders, F.W., and Simmons, D.G. (1991): Tracheal cilia response to exogenous Niacin in drinking water of turkey poults infected. North Carolina State Uni. 33:674-680 (Abstract)

5. Brown, R.E., Brain, J.D., and Wang, N. (1997): The avian respiratory system: A unique model for studies of respiratory toxicosis and for monitoring air quality. Environ Health Perspect (105):188-200
6. Aughey, E., and Frye, F.L. (2001): Comparative Veterinary Histology with Clinical Correlates. Manson Ltd. Lon. PP: 93-94

7. Eurell, J.C. (2004): Veterinary Histology. Teton New Media. PP: 48-49

8. Beytut,

E.

(2007):

Immunohistochemical diagnosis of Aspergillosis in Adult Turkeys. J. Vet. Anim. Sci. 31(2): 99-104

9. Baumel, J.J., King, A.S., Breazile, J.E., Evans, H.E., and Vandan Berge, J.C. (1993): Respiratory system. In: Hand book of Avian Anatomy Nomina Anatomica Avium 2nd (ed.): Club. Cambridge, Massachusetts. PP: 257-299

10. Bacha, W.J., and Bacha, L.M. (2000): Color Atlas of Veterinary Histology 2nd (ed.): Lippincott Williams \& Wilkins. PP: 175-190

11. Demirkan, A.Ç., Haziroglu, R.M., and Kurtul I. ( 2006): Air sacs (Sacci pneumatici) in mallard ducks (Anas platyrhynchos). Ankara Univ. Vet. Fak. Derg. 53: 75-78

12. Samuelson, D.A. (2007): Text book of Veterinary Histology. Saunders Elsevier. PP. 246-248

13. Jeffery, P.K.(2004): Structure and function of mucus-secreting cell 
of cat and goose airway epithelium. Exp. Eye. Res. 78(2): 187-96 (Abstract)

14. Banks, W.J. (1993): Applied Veterinary Histology. Mosby. Inc. PP: 390-407

15. Luna, L.G. (1968): Manual of histologic staining methods of the armed forces institute of pathology $3^{\text {rd }}$ (ed.): Mc Graw-Hill book Co. N.Y. PP: 32-153

16. Galigheer, A., and Kozloff, E.N. (1964): Essential practical microtechnique. Lee and Fabrigar, Philadelphia.

17. Singh, I. (1987): Lymphatics and lymphoid organs. Respiratory system. Text book of human histology. Jaypee Brother Medical Publishers. PP: 167-178 \& 190198.
18. Eurell, J.A., and Frappier, B.L. (2006): Text book of veterinary histology $6^{\text {th }}$ (ed.): Black Well USA.

19. Yildizi, H., Yilmaz B., and Arican, I. (2005): Morphological structure of the syrinx in the Bursa roller pigeon (Columba livia). Bull Vet. Inst. Pulawy 49: 323-327

20. McLelland, J., (1990): A Colour Atlas of Avian Anatomy. Wolfe Publishing Ltd. Eng. PP. 95-119

21. Daley, M., and Goller, F. (2004): Tracheal length changes during zebra finch song and their possible role in upper vocal tract filtering. J. Neurobiol. 59(3):319-30. (Abstract)

22. Pierko, M. (2008): Size of the upper respiratory tract with reference to the body in Scaup Aythyamarila. Electronic J. of Polish Agricultural Univ. (EJPAU) 11(4): 34

\section{دراسة نسجية لرغامي ذكور الديك الرومي المربى محليا (Meleagris) gallopava)

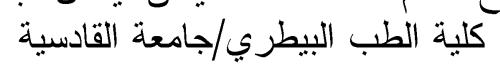 \\ عقيل محسن الموسوي \\ كلية الطب البيطري/جامعة ألكوفة}

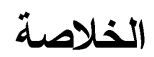

استخدم في الدراسة الحالية خمسة طيور من الديك الرومي (Meleagris gallopava ) سليمة بعمر سنة واحدة

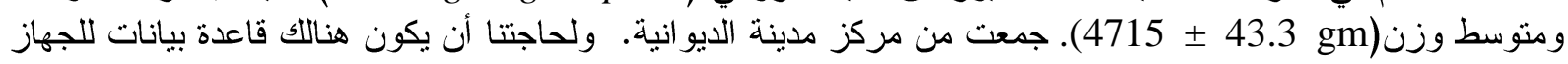

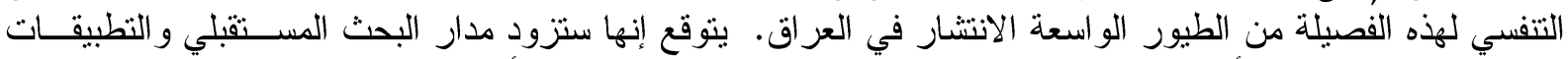

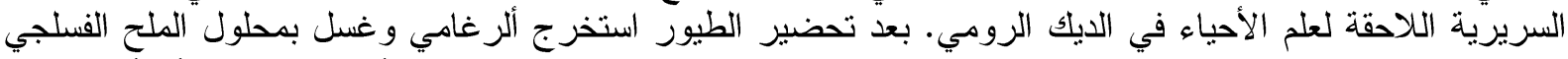

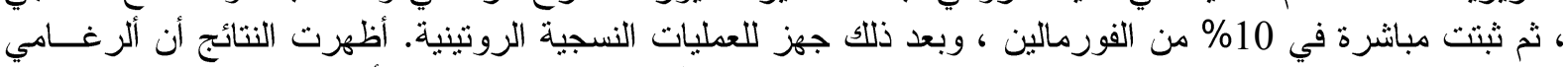

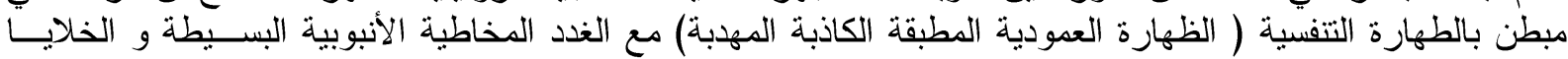

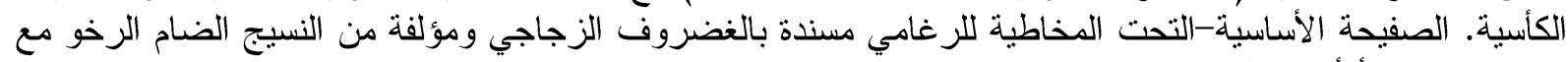

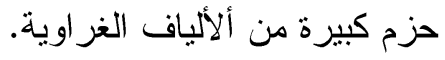

